\title{
HUBUNGAN HARGA DIRI DENGAN PRESTASI AKADEMIK MAHASISWA TINGKAT I PROGRAM STUDI D III JURUSAN KEPERAWATAN TANGERANG
}

\author{
*Lailatul Fadilah, *Rohanah
}

\begin{abstract}
Abstrak
Mahasiswa merupakan subjek yang memiliki potensi untuk mengembangkan pola kehidupanya, dan menjadi objek dalam keseluruhan bentuk aktifitas dan kreatifitasnya. Mahasiswa diharapkan mampu menunjukkan kualitas yang dimilikinya (Baharudin dan Makin, 2004). Kualitas mahasiswa dapat dilihat dari prestasi akademik yang diraihnya. Prestasi akademik merupakan perubahan dalam hal kecakapan tingkah laku ataupun kemampuan yang dapat bertambah selama beberapa waktu yang tidak disebabkan proses pertumbuhan, tetapi adanya situasi belajar. Situasi belajar yang sifatnya kompleks dan menyeluruh serta melibatkan interaksi beberapa komponen, sering ditemukan mahasiswa yang tidak dapat meraih prestasi akademik yang setara dengan kemampuan intelegensianya. Perbedaan individual dari factor kepribadian cenderung menentukan penyesuaian diri dan kualitas prestasi akademik mahasiswa. Persepsi yang positif terhadap kepribadian akan mempengaruhi konsep diri kearah yang positif, dan mendorong individu untuk meraih prestasi (Sahlan, 2000). Tujuan penelitian ini adalah untuk mengidentifikasi hubungan harga diri dengan prestasi akademik mahasiswa TK I Program Studi D III Jurusan Keperawatan Tangerang. Sampel penelitian berjumlah 127 responden yaitu seluruh mahasiswa TK I Prodi D III keperawatan dengan teknik total sampling. Analisa yang digunakan yaitu analisa univariat dan analisa bivariat menggunakan uji chi square dengan tingkat kemaknaan $(\alpha=0,05)$. Hasil penelitian menunjukkan bahwa tidak terdapat hubungan yang bermakna antara harga diri dengan prestasi kademik mahasiswa tingkat I Program Studi D III Keperawatan dengan nila p $=0.702$.
\end{abstract}

Kata Kunci : harga diri, prestasi akademik mahasiswa

*Poltekkes Kemenkes Banten 


\section{PENDAHULUAN.}

Mahasiswa merupakan subjek dengan individu lainnya (Baiquni, yang memiliki potensi untuk 2007).

mengembangkan pola kehidupanya, dan menjadi objek dalam keseluruhan bentuk aktifitas dan kreatifitasnya. Mahasiswa diharapkan mampu menunjukkan kualitas yang dimilikinya (Baharudin dan Makin, 2004). Kualitas mahasiswa dapat dilihat dari prestasi akademik yang diraihnya.

Prestasi akademik merupakan perubahan dalam hal kecakapan tingkah laku ataupun kemampuan yang dapat bertambah selama beberapa waktu yang tidak disebabkan proses pertumbuhan, tetapi adanya situasi belajar. Sehingga dipandang sebagai bukti usaha yang diperoleh mahasiswa (Sobar, 2006). Dalam situasi belajar yang sifatnya kompleks dan menyeluruh serta melibatkan interaksi beberapa komponen, sering ditemukan mahasiswa yang tidak dapat meraih prestasi akademik yang setara dengan kemampuan intelegensianya. Pada dasarnya prestasi akademik merupakan hasil interaksi dari berbagai faktor yang berbeda antara satu individu
Perbedaan individual dari factor kepribadian cenderung menentukan penyesuaian diri dan kualitas prestasi akademik mahasiswa. Faktor kepribadian seperti self image, kesadaran diri, ideal diri, motivasi, pengendalian dan harga diri memerlukan harmonisasi dalam proses belajar, yang akan mendukung terhadap hasil belajar (Wahyuni, 2007). Persepsi yang positif terhadap kepribadian akan mempengaruhi konsep diri kearah yang positif, dan mendorong individu untuk meraih prestasi (Sahlan, 2000).

Hal tersebut juga ditunjang oleh pendapat Coopersmith, 1967 (dalam Diana, 2007) yang mengatakan bahwa seseorang yang mempunyai harga diri yang tinggi cenderung aktif, ekspresif serta lebih sering mencapai sukses baik dalam bidang akademik maupun sosial.

Seseorang yang memandang dirinya negatif menganggap 
keberhasilan yang telah dicapai hanya sebagai kebetulan saja atau karena faktor keberuntungan saja. Sedangkan seseorang yang memandang dirinya positif akan menganggap keberhasilan sebagai adanya kemampuan.

Dari berbagai macam uraian tersebut peneliti berkeinginan untuk melakukan penelitian dengan judul "Hubungan Harga Diri dengan Prestasi Akademik Mahasiswa Tingkat I Jurusan Keperawatan Tangerang".

\section{Tujuan Penelitian}

Tujuan penelitian ini adalah untuk mengetahui hubungan antara Harga Diri dengan Prestasi Akademik Mahasiswa Tingkat I Program Studi D III Jurusan Keperawatan Tangerang.

\section{Metode Penelitian}

Penelitian ini merupakan penelitian kuantitatif dengan menggunakan desain penelitian cross sectional. Data dianalisis menggunakan analisis univariat dan bivariat. Sampel penelitian berjumlah 127 responden yaitu seluruh mahasiswa tingkat I
Program Studi D III keperawatan, tehnik pengumpulan data yang digunakan adalah total sampling. Alat pengumpulan data berupa kuesioner Analisa yang digunakan yaitu analisa univariat dan analisa bivariat menggunakan uji chi square dengan tingkat kemaknaan

$(\alpha=0,05)$.

\section{Hasil Penelitian}

a. Harga diri mahasiswa TK I DIII Keperawatan

Tabel 1

Distribusi frekuensi responden berdasarkan harga diri

\begin{tabular}{lcc}
\hline Harga diri & Jumlah & Persentase \\
\hline Tinggi & 61 & 48,0 \\
Rendah & 66 & 52,0 \\
\hline Total & 127 & 100,0 \\
\hline
\end{tabular}

Berdasarkan tabel 1 dapat diketahui bahwa dari 127 responden yang dilakukan penelitian didapatkan hasil yaitu 66 responden (52\%) memiliki harga diri rendah.

b. Prestasi akademik (IPK)

Prestasi akademik (IPK) di dapatkan hasil sebagai berikut: 
Tabel 2

Distribusi frekuensi responden berdasarkan prestasi akademik

\begin{tabular}{lcc}
\hline $\begin{array}{l}\text { Prestasi } \\
\text { akademik }\end{array}$ & Jumlah & $\begin{array}{c}\text { Persentase } \\
(\%)\end{array}$ \\
\hline Tinggi & 10 & 7,9 \\
Cukup & 117 & 92,1 \\
\hline Total & 127 & 100,0
\end{tabular}

Berdasarkan tabel 2 dapat diketahui bahwa dari 127 responden yang dilakukan penelitian sebagian besar 117 responden $(92,1 \%)$ prestasi akademik yang diperoleh responden adalah cukup.

c. Hubungan harga diri dengan prestasi akademik

\section{Tabel 3}

Distribusi frekuensi berdasarkan hubungan harga diri dengan prestasi akademik

\begin{tabular}{|c|c|c|c|c|c|c|c|}
\hline \multirow{3}{*}{$\begin{array}{c}\text { Harga } \\
\text { diri }\end{array}$} & \multicolumn{4}{|c|}{ Prestasi Akademik } & \multirow{2}{*}{\multicolumn{2}{|c|}{ Total }} & $\mathrm{P}$ \\
\hline & \multicolumn{2}{|c|}{ Tinggi } & \multicolumn{2}{|c|}{ Cukup } & & & Value \\
\hline & $\mathrm{n}$ & $\%$ & $\mathrm{~N}$ & $\%$ & $\mathrm{n}$ & $\%$ & \\
\hline Tinggi & 4 & 6,6 & 57 & 93,4 & 61 & 100 & \\
\hline Rendah & 6 & 9,0 & 60 & 91,0 & 66 & 100 & 0,746 \\
\hline Total & 10 & & 117 & & 127 & 100 & \\
\hline
\end{tabular}

Berdasarkan tabel 3 diatas hasil analisis hubungan antara harga diri dengan prestasi akademik diperoleh bahwa responden yang harga diri rendah ada 6 (9\%) memperoleh indeks prestasi tinggi dan 60 responden $(91 \%)$ memiliki harga diri rendah dengan memperoleh indeks prestasi cukup. Hasil uji statistik diperoleh nilai $\mathrm{p}=0.746$ maka dapat disimpulkan tidak ada hubungan yang signifikan antara harga diri dengan indeks prestasi mahasiswa TK I Program Studi D III Keperawatan.

\section{Pembahasan}

Hasil penelitian didapatkan bahwa ada 6 responden $(9,0 \%)$ yang harga diri rendah memperoleh indeks prestasi tinggi dan 60 responden $(91,0 \%)$ memiliki harga diri rendah dengan memperoleh indeks prestasi cukup. Hasil uji statistik diperoleh nilai $\mathrm{p}=0.746$ maka dapat disimpulkan tidak ada hubungan yang signifikan antara harga diri dengan indeks prestasi mahasiswa TK I Prodi D III Keperawatan.

Hasil penelitian menunjukkan bahwa 91,0 \% responden memiliki harga diri rendah dengan memperoleh prestasi akademik cukup. Harga diri merupakan bagian dari komponen konsep diri, dimana konsep diri merupakan salah satu factor yang mempengaruhi prestasi akademik. 
Harga diri merupakan aspek kepribadian yang pada dasarnya dapat berkembang. Kurangnya harga diri pada mahasiswa dapat mengakibatkan masalah akademik dan juga dapat mengakibatkan gangguan pada proses berfikir dan konsentrasi belajar (Rohmah, 2008).

Hasil penelitian menunjukkan tidak adanya hubungan antara harga diri dengan prestasi akademik hal ini sesuai dengan hasil penelitianpenelitian sebelumnya seperti Firmanto dan Anggi pada tahun 2010 yang menghubungkan konsep diri dan prestasi belajar siswa SMA Shalahuddin Malang yang secara statistik terdapat hubungan yang lemah dan tidak signifikan antara variabel konsep diri dan prestasi belajar. Ini juga didukung oleh penelitian yang dilakukan Herawati (2006) yaitu konsep diri siswa yang berprestasi belajar matematika dibawah rata-rata kelas. Didapatkan hasil bahwa terdapat hubungan yang sangat lemah dan tidak signifikan. Hal ini membuktikan bahwa prestasi belajar rendah tidak hanya dipengaruhi oleh konsep diri saja tetapi masih ada faktor lain yang juga merupakan faktor penyebab prestasi belajar, misalnya; minat, kemauan belajar, kesehatan, faktor keluarga, dan lingkungan disekitarnya.

Selain konsep diri dan motivasi berprestasi, masih ada faktor lain yang mempengaruhi prestasi akademik. Faktor lainnya yang tidak dikaji dalam peneliitian ini adalah faktor internal, yaitu kecerdasan, keadaan jasmani, kepribadian (kecemasan), fear of failure, dan faktor eksternal, yaitu perbedaan kelas sosial, kebudayaan, perbedaan daerah perkotaan/ pedesaan, lingkungan rumah, dan lingkungan sekolah.

Rola (2006) menyatakan factor yang mempengaruhi prestasi belajar adalah pengaruh keluarga dan kebudayaan, peranan konsep diri, pengaruh dari peran jenis kelamin, dan pengakuan dan prestasi. Soemanto (2006) menyatakan bahwa prestasi belajar dipengaruhi oleh beberapa factor antara lain konsep diri ( harga diri, gambaran diri, ideal diri), locus of control, kecemasan yang dialami, dan motivasi hasil belajar.

Oemar (2000) berpendapat bahwa nilai harga diri individu 
apabila rendah, akan diikuti motivasi belajar yang rendah pula, namun motivasi berprestasi bukan hanya dari factor harga diti saja melainkan ada factor internal, eksternal, dan pendekatan belajar. Hal ini sejalan dengan pendapat Fikri (2005) yang menyatakan bahwa factor yang mempengaruhi prestasi akademik selain konsep diri adalah intelegensia, minat, perhatian, kematangan emosional dan kesiapan peserta didik, dapat member pengaruh yang signifikan terhadap hasil belajar dalam meningkatkan proses dan hasil belajar yang pada akhirnya berpengaruh pada peningkatan prestasi.

Hasil penelitian yang menunjukkan bahwa tidak adanya hubungan antara harga diri dengan prestasi akademik tidak sejalan dengan penelitian-penelitian terdahulu seperti yang dilakukan oleh Sutera, dkk (2014) dimana hasil penelitiannya menunjukkan adanya hubungan yang bermakna antara harga diri dengan prestasi akademik.

Hasil penelitian Sulistiyowati (2008), tentang hubungan antara harga diri dengan motivasi beprestasi dalam belajar pada mahasiswa semester II D IV kebidanan UNS Surakarta, 2007, didapatkan adanya hubungan antara harga diri dengan motivasi berprestasi dengan nilai yang signifikan. Dimana harga diri merupakan aspek kepribadian yang pada dasarnya dapat berkembang. Kurangnya harga diri pada mahasiswa dapat mengakibatkan masalah akademik dan juga dapat mengakibatkan gangguan pada proses berfikir dan konsentrasi belajar (Rohmah, 2008).

Menurut Oemar, nilai harga diri individu apabila rendah, akan diikuti motivasi belajar yang rendah pula. Namun motivasi berprestasi bukan hanya dari faktor harga diri saja, melainkan ada faktor internal yang lain, eksternal dan pendekatan belajar.

Tidak ditemukannya perbedaan yang signifikan antara mahasiswa dengan prestasi yang tinggi dan rendah dapat disebabkan hal-hal yang berkaitan dengan kegiatan belajar. Dimana nilai IPK yang didapatkan merupakan nilai setelah perbaikan sehingga hasilnya sudah bagus diatas rata-rata yang ditentukan. Ini 
terlihat bahwa hasil pada penelitian ini menunjukan bahwa secara umum subyek memiliki prestasi akademik yang cukup tinggi.

\section{Simpulan}

Hasil penelitian menunjukkan bahwa 66 responden $(52,0 \%)$ memiliki harga diri rendah.

Hasil penelitian menunjukkan bahwa $117 \quad(92,1 \%)$ responden memperoleh indeks prestasi cukup.

Hasil penelitian menunjukkan tidak terdapat hubungan yang bermakna antara harga diri dengan prestasi kademik mahasiswa tingkat I Program Studi D III Keperawatan dengan nila $\mathrm{p}=0.702$. Hal ini membuktikan bahwa prestasi belajar rendah tidak hanya dipengaruhi oleh konsep diri saja tetapi masih ada faktor lain yang juga merupakan faktor penyebab prestasi belajar, misalnya; minat, kemauan belajar, kesehatan, faktor keluarga, dan lingkungan disekitarnya.

\section{Daftar Pustaka}

Baharudin \& Makin, M. (2004). Pendidikan Humanistik. Jakarta : Arruzz Media
Baiquni. (2007). Intelegensia bukan satu -satunya. http://www.epsikologi.com/acs.34/html

Fikri. (2005). Aktualisasi diri dan implikasinya pada pendidikan. http://.multiply.com/journal/item/ $\underline{23}$

Herawati. (2006). Konsep diri siswa yang berprestasi belajar matematik dibawah rata-rata kelas. Jakarta : Unika Atma Jaya

Oemar. (2000). Meningkatkan harga diri. http://www.e-psikologi.com

Rohmah. (2004). Mengapa harga diri itu penting. http://www.nsw.gov.au/mhcs/pub lication-pdfs/7075.INDpdf.

Rola, F. (2006). Hubungan konsep diri dengan motivasi berprestasi pada remaja. http://www. Digitizedlibrary.usu.ac.id/psikolo gi/html

Sahlan. (2000). Ajari anak sejak dini berprestasi.

http://www.AAsb/blogspot/re.s6 $\underline{70 / \mathrm{html}}$

Sobur. A. (2006). Psikologi Umum. Bandung : Pustaka Setia

Soemanto, W. (2006). Psikologi pendidikan. Jakarta : Rineka Cipta

Stuart, W \& Sundeen. (1998). Buku Saku Keperawatan Jiwa. Jakarta : EGC

Sulistiyowati. (2008). Hubungan antara harga diri dengan motivasi berprestasi dalam 
belajar pada mahasiswa semester

II $D \quad I V$ Kebidanan UNS

Surakarta 2007/2008.

http://www.uns.ac.id/sulistiyowat i/php

Wahyuni, A. (2007). Kegiatan

Belajar terhadap prestasi yang

dicapai.

http://www.achievment.com/html 